\title{
NEONATAL EXPOSURE TO CITALOPRAM, A SEROTONIN SELECTIVE REUPTAKE INHIBITOR, PROGRAMS A DELAY IN THE REFLEX ONTOGENY IN RATS
}

\author{
Teresa Cristina Bomfim de Jesus Deiró-2, Judelita Carvalho², Elizabeth do Nascimento', \\ Jaiza Maria Barreto Medeiros ${ }^{2}$, Fabiana Cajuhi', Kelli Nogueira Ferraz-Pereira ${ }^{7}$, Raul Manhães-de-Castro ${ }^{1}$
}

\begin{abstract}
Serotonin influences the growth and development of the nervous system, as well as its behavioral manifestations. The possibility exists that increased brain serotonin availability in young animals modulates their neuro-behavioral responses. This study investigated the body weight gain and reflex ontogeny of neonatal rats treated during the suckling period with two doses of citalopram $(5 \mathrm{mg}$, or $10 \mathrm{mg} / \mathrm{kg}$, sc, daily). The time of the appearance of reflexes (palm grasp righting, free-fall righting, vibrissa placing, auditory startle response, negative geotaxis and cliff avoidance) as well as the body weight evolution were recorded. In general, a delay in the time of reflex development and a reduced weight gain were observed in drug-treated animals. These findings suggest that serotoninergic mechanisms play a role in modulating body weight gain and the maturation of most reflex responses during the perinatal period in rats.
\end{abstract}

KEY WORDS: serotonin, programming, SSRI, citalopram, reflex development.

\section{Exposição neonatal ao citalopram, um inibidor seletivo da recaptação de serotonina, programa retardo na ontogênese reflexa em ratos}

\begin{abstract}
Resumo - A serotonina influencia o crescimento e o desenvolvimento do sistema nervoso e sua expressão comportamental. $\mathrm{O}$ aumento da disponibilidade de serotonina no cérebro de ratos jovens parece modular as respostas neurocomportamentais. Neste estudo, foram investigados o ganho de peso corporal e a ontogênese dos reflexos em ratos neonatos, tratados diariamente, durante o período de aleitamento, com duas doses de citalopram (5 ou $10 \mathrm{mg} / \mathrm{Kg}$ de peso corporal, via subcutânea). Foram avaliados, o tempo de aparecimento dos reflexos (preensão palmar, endireitamento, colocação pelas vibrissas, resposta ao susto, geotáxico negativo e aversão ao precipício), e a evolução do peso corporal. Foi observado atraso no tempo de desenvolvimento de alguns reflexos e redução no ganho de peso corporal. Os achados em ratos sugerem que as alterações no ganho de peso corporal e na maturação dos reflexos são programadas, durante o período perinatal, com participação de mecanismos serotoninérgicos de modulação.
\end{abstract}

PALAVRAS-CHAVE: serotonina, programação, ISRS, citalopram, desenvolvimento reflexo.

Environmental impacts during the perinatal period can persistently affect morphofunctional patterns in a variety of physiological systems ${ }^{1,2}$. During this period, the high speed of cellular events results in a higher vulnerability of the nervous system (NS), so that distress acting upon it could alter the structure and function in age-related, developmental processes, such as maturation of most reflex responses and motor responses ${ }^{3}$. In the NS, the sequence of cellular events during the early period of life, embryogenesis, and nursing, helps determine both the definitive neurochemical composition and the morphofunctional structure of the mature organism ${ }^{4}$. These events would involve a mechanism called "programming". In this phenomenon, an environmental alteration during a critical developmental period would have persistent effects on the structure and function of the body ${ }^{5,6}$. Experimental evidence indicates that serotonin can also influence embryogenesis and growth ${ }^{7,8}$ by acting, presumably, as a developmental signal ${ }^{9}$ or as a neurotrophic factor ${ }^{10}$. Furthermore, serotonin seems to play a role in regulating the development of the mammalian brain through actions on the serotoninergic neurons themselves ${ }^{8,11,12}$. Serotonin has been

'Departamento de Nutrição, Centro de Ciências da Saúde, Universidade Federal de Pernambuco (UFPE), Recife PE, Brasil; '²epartamento de Ciências da Nutrição, Universidade Federal da Bahia (UFBA), Salvador BA, Brasil.This study received financial support from CNPq and PROIN/CAPES/PQI.

Received 4 March 2008, received in final form 25 July 2008. Accepted 6 August 2008.

Dr. Raul Manhães-de-Castro - Avenida Morais Rego 1235 - 50670-901 Recife PE - Brasil. E-mail: raulmanhaesdecastro@yahoo.com.br 
shown to have multiple functions as a neurotransmitter, which it realizes by exerting modulating effects on the neural excitability ${ }^{13}$. There is a large amount of evidence of its participation in pain sensitivity, motor activity, body thermoregulation, sleep, feeding behavior, and mood ${ }^{14,15}$. Encephalic areas that are known to be involved in psychomotor processes, such as the brainstem, cerebellum, diencephalon, basal ganglia and cerebral cortex, are innervated by serotoninergic pathways from raphe nuclei ${ }^{16}$. Growth and development of the central nervous system occur with great intensity during the rat's gestation and suckling period ${ }^{17}$. In these phases, the brain structures are highly vulnerable to several types of insult. In the rat, the first serotoninergic neurons appear between the $12^{\text {th }}$ and the $14^{\text {th }}$ day of gestation ${ }^{18}$. The second and third week of postnatal life are distinguished by an abundant dendritic arborization of serotoninergic axons in the cerebral and cerebellar cortex, in the hippocampus, and in striatum ${ }^{18}$. The final density and location of the serotoninergic neuron terminals are achieved only during postnatal maturation ${ }^{18,19}$.

During pregnancy or the suckling period, pharmacological or nutritional manipulations can induce drastic morphological and functional changes in the growth and development of the nervous system ${ }^{20-22}$. Furthermore, the reflex maturation constitutes an indicator of the development of the nervous system ${ }^{23}$. Retardation of the reflex ontogeny in malnourished rats has been observed ${ }^{24}$. High levels of 5-HT and 5-HIAA were found in the brains of undernourished animals that were up to 300 days old ${ }^{25}$. In addition, serotonin and serotoninergic drugs have anorexic properties ${ }^{26,27}$. The selective serotonin reuptake inhibitors increase the availability of serotonin in the synaptic $\mathrm{cleft}^{28}$. Neonatal manipulation with sertraline also caused a delay in somatic ontogenesis and in the maturation of some reflexes ${ }^{29}$.

Thus, the possibility exists that the use of serotoninergic agents in the initial phase of life could have some effects on the body growth and sensorimotor functions. To this end, we observed (in a previous work) that rats neonates, treated with citalopram, showed a retardation of somatic maturation and a decrease in body weight gain ${ }^{30}$. The objective of this study was to test the hypothesis that the administration of citalopram, a highly selective serotonin reuptake inhibitor ${ }^{31}$, in rats during the suckling period - the so-called brain growth spurt - results in adaptive changes in the appearance time of congenital reflexes.

\section{METHOD}

\section{Animals}

Wistar male rats from the colony of the Nutrition Department - Federal University of Pernambuco - Brazil were coupled to obtain litters. Between gestation and the end of the experiment, the animals were housed in polyethylene cages $(30 \times 27 \times 47)$.
Male pups from different mothers were randomly distributed in litters of 6 neonates, 24 hours after their births. Each pup was labeled with a mark of methyl violet solution on its skin, which provided identification during the experiment. Each litter was breastfed by one of the dams until the $21^{\text {st }}$ post-natal day (the day of birth was considered to be day zero). The animals were maintained at a room temperature of $23 \pm 19 \mathrm{C}$, on a light-dark cycle of 12/12 hours (light on 6:00 a.m. to 6:00 p.m.) with free access to meals (Labina-Purina of Brazil) and water. The experimental protocol of this paper was approved by the Ethical Committee for Animal Experimentation (CEEA) from the Federal University of Pernambuco, in agreement with the National Institute of Health guide for the Care and Uses of Laboratory Animals.

\section{Pharmacological treatment and experimental groups}

A blind experiment was performed to prevent identification of the experimental groups. The animals of the different groups were simultaneously evaluated. According to the experimental treatment, three groups ( $n=27$ each one) of suckling rats were distributed as follows: group Cit5 (5 mg/kg, sc); group Cit10 (10 mg/kg, sc); and one control group receiving an equivalent volume of saline solution ( $\mathrm{NaCl} 0.9 \%, \mathrm{sc}$.). During the experiment, one neonate in the Cit 5 group died. Therefore, 80 rats were evaluated during the whole experiment. The time for reflex maturation and the body weight were determined. Citalopram (H.Lundbeck A/S, Copenhagen-Valby, Denmark) was dissolved in a saline solution and injected at a concentration of 1 $\mathrm{mL} / 100 \mathrm{~g}$ b.w. The treatment was applied daily from the $1^{\text {st }}$ to the $21^{\text {st }}$ postnatal day (suckling period).

\section{Body weight}

The measurement of body weight was performed on days 1, 3, 7, 14 and 21, between 10:00 p.m. and 1:00 p.m, using a Marte scale, Brazil-São Paulo, SP (100 mg precision).

\section{Reflex testing}

The reflex tests ${ }^{23}$ were carried out daily from the $1^{\text {st }}$ to the $21^{\text {st }}$ postnatal day (Table 1), and were conducted between 11:00 a.m. and 1:00 p.m. The progress of the individuals was followed throughout the experiment. The time of the appearance of each reflex was defined as the first day of its occurrence during a period of three consecutive days.

\section{Statistical analysis}

After preliminary testing to identify the distribution normality and homogeneity among the groups, statistical analyses were performed: a two way repeated measures ANOVA test on the $1^{\text {st }}, 3^{\text {th }}, 7^{\text {th }}, 14^{\text {th }}$ and $21^{\text {st }}$ day for the body weight followed by a post-hoc Holm-Sidak test were used for multiple comparisons. The Kruskal-Wallis analysis of variance, followed by Dunn's test, was used to compare the time appearance of the reflexes between each citalopram dose and saline. The level of significance was $\mathrm{p}<0.05$. 
Table 1. Description of the tests reflexes.

\begin{tabular}{|c|c|c|}
\hline Reflex & Eliciting stimuli & Response \\
\hline Palmar-grasp & $\begin{array}{l}\text { The fore paws of the rat are stroked gently with } \\
\text { a cylindrical stick of 1mm thickstick (paper-clip) }\end{array}$ & $\begin{array}{l}\text { Digits flex to grasp the stick. The disappearance } \\
\text { date is taken. }\end{array}$ \\
\hline $\begin{array}{l}\text { Righting } \\
\text { (recovery of the decubitus) }\end{array}$ & The rat is placed with the back on a surface & Its rolls and turns over on to ventral surface, in $10 \mathrm{~s}$. \\
\hline $\begin{array}{l}\text { Free-fall righting } \\
\text { (acceleration righting) }\end{array}$ & $\begin{array}{l}\text { The rat is dropped, back downwards, from } 35 \mathrm{~cm} \\
\text { on to cotton wool pad }\end{array}$ & Its turns in mid-air to land on all fours \\
\hline Negative-Geotaxis & $\begin{array}{l}\text { The rat is placed on the surface tilted to } 45^{\circ} \text {, } \\
\text { with its head turned back to the inferior area }\end{array}$ & $\begin{array}{l}\text { Its returns in direction to the superior area of the } \\
\text { tilted plan, in } 10 \mathrm{~s} \text {. }\end{array}$ \\
\hline Cliff-avoidance & $\begin{array}{l}\text { The rat is put on the edge of table, with nose } \\
\text { and fore feet just over edge }\end{array}$ & It moves away from "cliff", in $10 \mathrm{~s}$. \\
\hline Auditory-startle response & $\begin{array}{l}\text { Sound stimulus: snap of rat trap closing on } \\
\text { wooden base }\end{array}$ & $\begin{array}{l}\text { Sudden, brief extension of hind limbs (which raise } \\
\text { hind-quarters) }\end{array}$ \\
\hline Vibrissa-placing & $\begin{array}{l}\text { The rat is held by the tail, the head facing the } \\
\text { edge of the table, vibrissa just touching verti- } \\
\text { cal surface }\end{array}$ & $\begin{array}{l}\text { It lifts its head and extends the fore limbs in di- } \\
\text { rection the table, in } 10 \mathrm{~s} \text {. }\end{array}$ \\
\hline
\end{tabular}

Modified from Smart and Dobbing (1971).

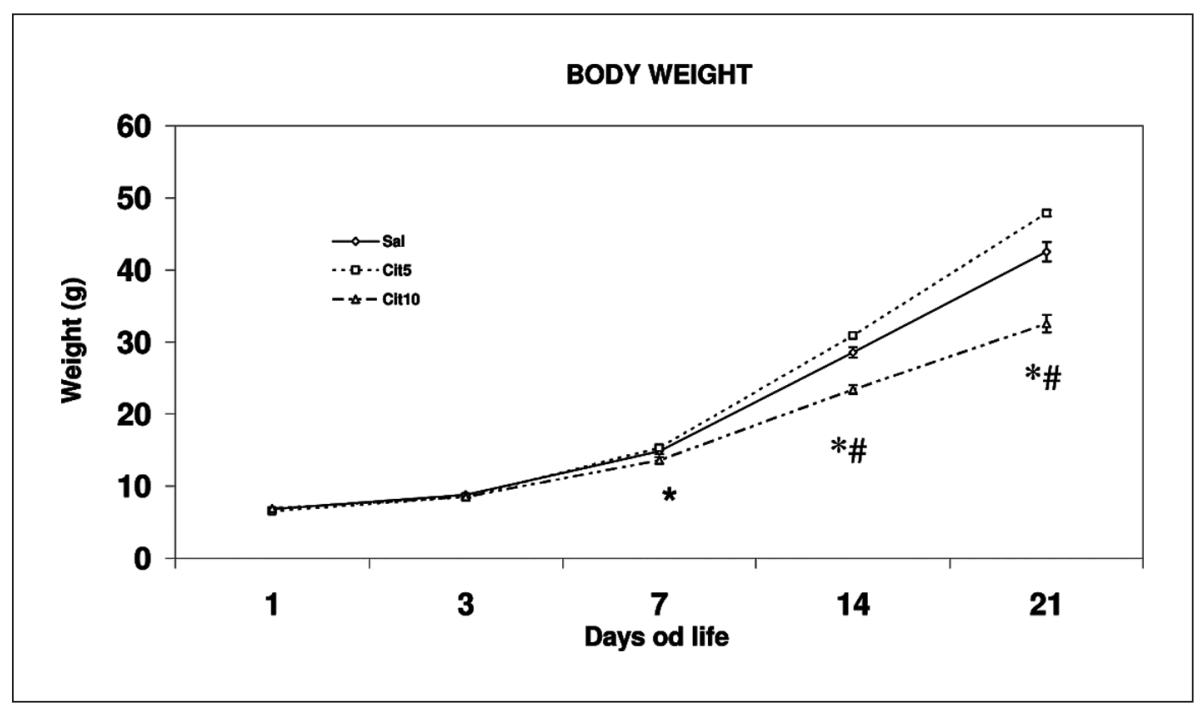

Fig 1. Body weight of suckling rats from the $1^{\text {st }}, 3^{\text {th }}, 7^{\text {th }}, 14^{\text {th }}$ to $27^{\text {st }}$ day of life, treated with citalopram from the $7^{\text {st }}$ to the $27^{\text {st }}$ day of life. Two way repeated measures ANOVA; Holm-Sidak test $\left(F_{2.399}=13.134\right)$ : ${ }^{*}$ Comparisons of Cit $10 \mathrm{mg}$ with saline ( $\left.p<0.05\right)$; \#Comparisons of Cit $5 \mathrm{mg}$ with saline $(p<0.05)$.

Table 2. Maturation of the reflexes of suckling rats treated with citalopram from the $7^{\text {st }}$ to the $27^{\text {st }}$ day of life.

\begin{tabular}{|c|c|c|c|c|c|c|c|}
\hline \multirow[t]{3}{*}{ Reflexes (days) } & \multicolumn{7}{|c|}{ Groups } \\
\hline & \multicolumn{2}{|c|}{ Saline } & \multicolumn{2}{|c|}{ Cit 5} & \multicolumn{2}{|c|}{ Cit 10} & \multirow[t]{2}{*}{$\mathrm{p}$-value } \\
\hline & Median & (range) & Median & (range) & Median & (range) & \\
\hline Palmar grasp & 2.5 & $(1.0-9.0)$ & 6.5 & $(3.0-5.0)^{\mathrm{a}}$ & 6.0 & $(5.0-9.0)^{\mathrm{a}}$ & $<0.001^{\#}$ \\
\hline Righting & 5.0 & $(3.0-9.0)$ & 8.0 & $(4.0-9.0)$ & 9.0 & $(5.0-10.0)^{\mathrm{a}}$ & $=0.03^{\#}$ \\
\hline Vibrissa placing & 11.0 & $(8.0-15.0)$ & 13.0 & $(11.0-16.0)^{\mathrm{a}}$ & 13.0 & $(11.0-17.0)^{a}$ & $<0.001^{\#}$ \\
\hline Cliff avoidance & 8.0 & $(7.0-14.0)$ & 10.0 & $(8.0-13.0)$ & 11.0 & $(7.0-18.0)$ & \\
\hline Negative geotaxis & 12.0 & $(8.0-16.0)$ & 12.0 & $(9.0-16.0)^{a}$ & 13.0 & $(12.0-18.0)^{\mathrm{b}}$ & $<0.001^{\#}$ \\
\hline Auditory startle & 11.0 & (11.0-14.0) & 12.0 & $(12.0-18.0)$ & 13.0 & $(12.0-18.0)^{a}$ & $=0.012^{\#}$ \\
\hline Free-fall righting & 14.0 & $(12.0-18.0)$ & 17.0 & $(16.0-19.0)^{a}$ & 16.0 & $(14.0-21.0)^{a}$ & $<0.001^{\#}$ \\
\hline
\end{tabular}

"Kruskal-Wallis test; Dunn's test: ${ }^{\mathrm{a}}$ multiple comparisons with the saline group; ${ }^{\mathrm{b}}$ multiple comparisons with the Cit 5 group. 


\section{RESULTS}

Compared with the saline group, ANOVA revealed a lower body weight in the Cit10 group from the $7^{\text {th }}$ to $27^{\text {st }}$ day $(p<0.05)$, and in the Cit5 group from the $14^{\text {th }}$ to $21^{\text {st }}$ day $(\mathrm{p}<0.05)$ (Fig 1$)$.

The time it takes for the maturation of physical features (Table 2) showed statistically significant alterations when compared to the saline group in the palmar grasp ( $H=14.842 ; p<0.001)$; the development of this reflex was delayed in the Cit5 $(p<0.05)$ and Cit10 groups $(p<0.05)$. The righting reflex also differed between groups $(H=11.827 ; p=0.003)$, where a delay in this physical characteristic occurred in the Cit10 group $(p<0.05)$. In the placing of the vibrissa, presented statistical differences between groups $(H=15.531 ; p<0.001)$; this physical feature was delayed in Cit5 $(p<0.05)$ and Cit10 groups $(p<0.05)$. The acoustic startle response $(H=8.835 ; p=0.012)$ was delayed in the Cit10 group ( $<<0.05)$. The free-fall righting response showed statistical differences between groups $(H=23.443 ; p<0.001)$, with a delay occurring in the Cit5 $(p<0.05)$ and Cit10 groups $(p<0.05)$. The negative geotaxis reflex $(H=21.132 ; p<0.001)$ showed delays in the $\mathrm{Cit} 5$ group $(p<0.05)$ when compared to the saline group, and in the Cit10 group $(p<0.05)$ when compared to the Cit5 group. The Cliff avoidance was not statistically significant different among the groups.

\section{DISCUSSION}

The present study showed that the chronic administration of citalopram during the critical period of brain development in rats delays the body weight gain and the appearance time of reflexes. The action of the drug on serotoninergic signaling pathways is likely responsible for these effects since SSRIs increase the serotonin release in the synaptic cleft $^{28}$.

Some studies in humans have observed the use of SSRIs in young children, suggesting repercussions such as affective alterations ${ }^{32}$. The neonatal manipulation of the $5-\mathrm{HT}$ system with SSRI causes repercussions in adult rats such as the occurrence of depression-like effects ${ }^{33}$ and a reduction of aggressiveness ${ }^{22}$. In the present study, we show an anorexic effect of citalopram in neonatal rats. Recently, we showed a decrease of body weight gain and a reduction of aggressiveness in the adult rats treated with citalopram early in life as well ${ }^{22,33}$. These findings were hypothesized to be associated with serotoninergic pathways because of serotonin's inhibitory action on food intake ${ }^{27,34,35}$.

Alterations in the appearance of reflexes indicate a correlation between the biochemical and structural development and ontogenesis of the nervous system ${ }^{36}$. For example, the repercussions of other neonatal manipula- tions - such as early malnutrition - on the development of the structural, neurochemical and functional integrity of the nervous cells are well known'. The amount of brain monoamines present during development increases more quickly after birth ${ }^{37}$. Rats submitted early in life to low protein diets reveal altered brain levels of noradrenaline, dopamine, and serotoni ${ }^{38-40}$. High levels of 5-HT and 5HIAA were found in the brains of undernourished animals that were up to 300 days old ${ }^{25}$. It is well established that undernourished rats exhibit a delay in the development of reflexes, such as palm grasping, the startle response, and free-fall righting ${ }^{24}$.

Corroborating these hypotheses, it is possible that increased serotonin availability, when provoked by the SSRI treatment, could cause the delay in the reflexes. In this sense, an increase of the latency of the startle response in adult rats that were treated with fluoxetine during the neonatal period was shown ${ }^{41}$. This fluoxetine effect was reduced by m-chlorophenylpiperazine, a $5-\mathrm{HT}_{1 \mathrm{~B} / 2 \mathrm{C}}$ agent, thus suggesting serotoninergic modulation in the reflex elicitation ${ }^{41}$. In addition, treatment with fluoxetine diminished the locomotor activity in young rats ${ }^{42}$. Furthermore, there is evidence of the involvement of 5-hydroxytryptamine $_{1 \mathrm{~B}}$ autoreceptors in the enhancement of serotonin turnover in the mouse brain following repeated treatments with fluoxetine ${ }^{43}$.

Collectively, the observations in the present study indicate that serotoninergic mechanisms of neurotransmission after chronic treatment with citalopram, a SSRI, are involved in the body weight gain and the emergence of the reflexes. Several lines of evidence indicate that the immediate post-natal period is of particular importance for the long-term programming of nervous functions in the rodent. Notably, the development of the hypothalamic appetite regulatory network in rats and mice occurs predominantly after birth ${ }^{44-47}$. It therefore remains to be determined to what extent the altered regulatory action of 5-HT on the ontogenesis of reflexes and on body weight control is dependent on the type and subtype of serotonergic receptors, as well as on the developmental period during which serotonin modulation takes place.

In conclusion, the results showed that treatment with citalopram, during the suckling period, delayed the body weight gain and the development of early behavioral expressions. This evidence supports the hypothesis that persistent morphological or functional alterations were produced during the period of fast brain development, indicating the participation of the serotoninergic mechanisms in these events. These data are consistent with the idea that changes in reflex ontogeny are programmed with important participation of serotoninergic modulation during the perinatal period in rats. 


\section{REFERENCES}

1. Barker DJP. In utero programming of chronic disease. Clin Sci 1998;95: 115-128.

2. Toscano AE, Manhães-de-Castro R, Canon F. Effect of a low-protein diet during pregnancy on skeletal muscle mechanical properties of offspring rats. Nutrition 2008;24: 270-278.

3. Noback CR, Eisenman LM. Some effects of protein-calorie undernutrition on the developing central nervous system of the rat. Anat Rec 1981;201:67-73.

4. Morgane PJ, Miller M, Kemper T, et al. The effects of protein malnutrition on the developing central nervoussystem in the rat. Neurosci Biobehav Rev 1978;2:137-230.

5. Lucas A. Programming by early nutrition in man. Ciba Foundation symposium 1991;156:38-50.

6. Lucas A. The developmental origins of adult health and well-being. Adv Exp Med Biol 2005;569:13-15.

7. Palén K, Thörneby L, Emanuelsson H. Effects of serotonin antagonists on chick embryogenesis. Wilhelm Roux's. Arch Dev Biol 1979;187:89-103.

8. Whitaker-Azmitia PM. Role of serotonin and other neurotransmitter receptors in brain development: basis for developmental pharmacology. Pharmacol Rev 1991;43:553-561.

9. Liu J, Lauder JM. Serotonin promotes region-specific glial influences on cultures serotonin and dopamine neurons. Glia 1992;5:306-317.

10. Yan W, Wilson CC, Haring JH. 5- $\mathrm{HT}_{1 \mathrm{~A}}$ receptors mediate the neurotrophic effect of serotonin on developing dentate granule cells. Dev Brain Res 1997;98:185-190.

11. Whitaker-Azmitia PM, Azmitia EC. Autoregulation of fetal serotonergic neuronal development: role of high affinity serotonin receptors. Neurosci Letters 1986;67:307-312.

12. Shemer AV, Azmitia EC, Whitaker-Azmitia PM. Dose-related effects of prenatal 5-methoxytryptamine (5-MT) on development of serotonin terminal density and behavior. Dev Brain Res 1991;59:59-63.

13. Aghajanian GK, Marek GJ. Serotonin induces excitatory postsynaptic potentials in apical dendrites of neocortical pyramidal cells. Neuropharmacology 1997;36:589-599.

14. Chopin P, Moret C, Briley M. Neuropharmacology of 5-hydroxytryptamine $_{1 B / 1 D}$ receptor ligands. Pharmacol Ther 1994;62:385-405.

15. Olivier B, Mos J, Van Oorschot R, Hen R. Serotonin receptors and animal models of aggressive behavior. Pharmacopsychiat 1995;28:S89-S90.

16. Jacobs BL, Azmitia EC Structure and function of the brain serotonergic system. Physiol Rev 1992;72:165-229.

17. Morgane PJ, Austin-Lafrance RJ, Bronzino J, et al. Prenatal malnutrition and development of the brain. Neurosci Biobehav Rev 1993:17:91-128.

18. Lidov HGW, Molliver MEA. Immunohistochemical study of serotonin neuron development in the rat: ascending pathways and terminal fields. Brain Res Bull 1982;8:389-416.

19. Wallace JA, Lauder JM. Development of the serotoninergic system in the rat embryo immunocytochemical study. Brain Res Bull 1983;10:459-479.

20. Noback CR, Eisenman LM. Some effects of protein-calorie undernutrition on the developing central nervous system of the rat. Anat Rec 1981:201:67-73.

21. Manhães-deCastro R, Cabral-Filho JE, Costa JA, Costa FBR, Gallindo MAC, Hecksher CA. Neonatal treatment with naloxone causes permanent hyperalgesy in rats. Braz J Med Biol Res 1993;26:747-751.

22. Manhães-de-Castro R, Barreto-Medeiros JM, Mendes-da-Silva C, et al Reduction of intraspecific aggression in adult rats by neonatal treatment with a selective serotonin reuptake inhibitor. Braz J Med Biol Res 2001;34:121-124.

23. Fox MW. Reflex-ontogeny and behavioural development of the mouse Anim Behav 1965:13:234-241.

24. Smart JL, Dobbing J. Vulnerability of developing brain. VI. Relative effects of foetal and early postnatal undernutrition on reflex ontogeny and development of behaviour in the rat. Brain Res 1971;33:303-314.
25. Stern WC, Miller M, Forbes WB, Morgane PJ, Resnick O. Ontogeny of the levels of biogenic amines in various parts of the brain and in peripheral tissue in normal and protein malnourished rats. Exp Neurol 1975;49:314-326.

26. Moses PL, Wurtman RJ. The ability of certain anorexic drugs to suppress food consumption depends on the nutrient composition of test diet. Life Sci 1984;35:1297-1300.

27. Clifton PG, Lee MD. Fluoxetine hypophagia? Is there a role for serotoninergic mechanisms in some circumstances. Trends Pharmacol Sci 1997;18: $21-25$

28. Hyttel J. Pharmacological characterization of selective serotonin reuptake inhibitors (SSRIs). Int J Psychopharmacol 1994;9(Suppl):S19-S26.

29. Deiró TCBJ, Manhães-de-Castro R, Cabral-Filho JE, et al. Sertraline delays the somatic growth and reflex ontogeny in neonate rats. Physiol Behav 2006;82:338-344.

30. Deiró TC, Manhães-de-Castro R, Cabral-Filho JE, et al. Neonatal administration of citalopram delays somatic maturation in rats. Braz J Med Biol Res 2004;37:1503-1509.

31. Baumman P. Pharmacology and pharmacokinetics of citalopram and others SSRIs. Int Clin Psychopharmacol 1996;11(Suppl 1):S5-S11.

32. Riddle MA, Kastelic EA, Frosch E. Pediatric Psychopharmacology. J Child Psychol Psychiatry 2001;42:73-90.

33. Hansen HH, Sánchez. Neonatal administration of selective serotonin reuptake inhibitor LU 10-34-C increases forced swimming-induced immobility of adults rats. Pharmacol Res 1997;283:1333-1341.

34. Halford JCG, Blundell JE. Metergoline antagonize fluoxetine-Induced suppression of food intake but not changes in the behavioral satiety sequence. Pharmacol Biochem Behav 1996;54:745-751.

35. Halford JCG, Blundell JE. Pharmacology of appetite suppression. Prog Drug Res 2000;54:26-58.

36. Adlard BPF, Dobbing J. Elevated acetylcholinesterase activity in adult rat brain after undernutrition in early life. Brain Res 1971;30:198-199.

37. Loizou LA, Salt P. Regional changes in monoamines of the rat brain during postnatal development. Brain Res 1970;20:467-470.

38. Resnick O, Miller M, Fobs W, et al. Developmental malnutrition protein: influences on the central nervous system of the rat. Neurosci Biobehav Rev 1979;4:232-246.

39. Wiggins RC, Fuller G, Enna SJ. Undernutrition and the development of brain neurotransmitter systems. Undernutr Brain Dev 1984;35: 2085-2094

40. Chen JC, Tonkis J, Galler JR, Volicer L. Effect of prenatal malnutrition on release of monoamines from hippocampal slices. Life Sci 1995;57: $1467-1475$.

41. Dow-Edwards DL. Modification of acoustic startle reactivity by cocaine administration during the postnatal period: comparison wit a specific serotonin reuptake inhibitor. Neurotoxicol Teratol 1996;18:289-296.

42. Stanford JA, Currier TD, Gerhardt GA. Acute locomotor effects of fluoxetine, sertraline and nomifensine in young versus aged fischer 344 rats. Pharmacol, Biochem Behav 2002;71:325-332.

43. Stenfors C, Ross SB. Evidence for involvement of 5-hydroxytryptamine $_{1 \mathrm{~B}}$ autoreceptors in the enhancement of the serotonin turnover in the mouse brain following repeated treatment with fluoxetine. Life Sci 2002;71:2867-2880

44. Allen RG, Pintar JE, Stack J, Kendall JW. Biosynthesis and processing of proopiomelanocortin-derived peptides during fetal pituitary development. Dev Biol 1984;102:43-50.

45. Woodhams PL, Allen YS, McGovern J, et al. Immunohistochemical analysis of the early ontogeny of the neuropeptide Y system in rat brain. Neuroscience 1985;15, 173-202.

46. Kagotani Y, Hashimoto T, Tsuruo Y, Kawano H, Daikoku S, Chihara K. Development of the neuronal system containing neuropeptide $Y$ in the rat hypothalamus. Int J Dev Neurosci 1989;7:359-374.

47. Grove KL, Smith MS. Ontogeny of the hypothalamic neuropeptideY system. Physiol Behav 2003;79:47-63 